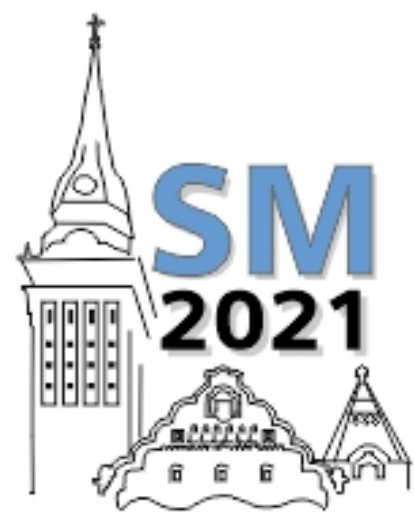

26th International Scientific Conference Strategic Management and Decision Support Systems in Strategic Management

21st May, 2021, Subotica, Republic of Serbia

Zsuzsanna Szeiner

J. Selye University,

Komárno, Slovakia

szeinerzsu@gmail.com

\section{Ádám Kovács}

J. Selye University,

Komárno, Slovakia

adamkovacs0823@gmail.com
Tibor Zsigmond

J. Selye University

Komárno, Slovakia

zsigmond.tibor95@gmail.com

József Poór

J. Selye University,

Komárno, Slovakia

poorj@ujs.sk

\title{
CONSULTING DURING THE CORONAVIRUS - IN THE LIGHT OF AN EMPIRICAL SURVEY
}

\begin{abstract}
Relatively little and accurate information about management consulting and its market is available to interested readers. Therefore, in this article, we are committed to presenting the most important global trends from various sources, analyzing the main features of the development of the European, Central and Eastern European, as well as the Hungarian consulting markets. The consulting sector - among several other industries, has been affected negatively by the emergence of Corona crisis. Consulting, characterized by stable growth and expansion before the pandemic, is estimated to have declined by 17-18 percent in 2020. However, different experts agree that consulting industry will recover faster from the current crisis than before. The pandemic has caused radical changes in the way we work and communicate, and consultants are ready to keep with the flow. One of the key questions of our empirical study in Hungary was the extent to which each consulting organization experienced an economically negative situation, the areas where there was a decrease or an increase, and the extent to which they see new opportunities for the future. Based on the results obtained, we found that the examined organizations were negatively affected by the crisis in terms of sales and services, but a significant part of the organizations also see new opportunities in the current situation for the future.
\end{abstract}

Keywords: management consultancy, trends, Central and Eastern Europe, impact of COVID on consulting, Hungary

\section{INTRODUCTION}

Consulting as a business service appeared about 150 years ago, during the Second Industrial Revolution, first in the United States (Poór, 2016). Nowadays, consulting has covered almost every area of business. Its focus areas have changed significantly over the past decades. The development of counseling from its inception to the present day can be discussed in a number of divisions. Due to the limited space available, the following should be highlighted in this regard:

- The most significant and longest-standing trend was the school of scientific management, which was able to influence this field for nearly eighty years. The main reason for its creation is the increased need for efficiency testing and its improvement in the field of management and other areas of economic life. In Europe, the first major advisory bodies appeared in England, France and Germany. Special mention should be made of the advisory trend that has developed in Germany, which has set an example for many Eastern European countries to follow. Just before the end of World War I, the RKW (Rationalisierung-Kuratorium der Deutschen Wirtschaft) was established in Germany in 1917 and the REFA (Reichsausschuss für Arbeitsstudien, now Arbeitsstudien und Betriebsorganisation) was established in 1925. They provided efficiency gains and the 
spread of conscious plant organization through state-subsidized means in all spheres of the economy. These organizations have made a significant contribution to the fact that, in addition to large companies, German small and medium-sized companies employ consultants long ago.

- As a result of excessive industrial orientation, many social scientists have sought to provide more humane production conditions for workers. The second wave was the emergence of human relations, in the 1920s. Its best-known representative is George Elton Mayo, who noticed the link between effectiveness and mental health and then made suggestions for reducing stress at work.

- Management and organization consultants: this include traditional management consulting firms. Their consulting practices are typically built around the field of corporate strategic consulting. These include the earlier mentioned McKinsey and Co., Booz and Co., Boston Consulting Group, and others (Pereira-Ramos, 2017).

- Consultant companies based on an accounting-financial professional background: the oldest organizations in the field of consulting. In terms of their professional profile, these firms grew out of some field of accounting or finance in the 1800 s and have now grown into global corporate empires. They are the so-called "First generation consultants" or "large audit firms" (Plunkett, 2018).

- Business Technology Consultants: This includes consulting firms that were formed in the 1950s and beyond. Their primary area of expertise is business technology consultancies. Typically, they grew out of the manufacturing, application development or consulting circles of the IT industry, and then appeared on the consulting market by purchasing and acquiring the complete consulting business units of serious consulting companies. These include PWC, Unisys, SAP, etc. (Poór, 2016)

- The digital revolution that has unfolded in recent years has made IT and outsourcing consulting increasingly important. One important phenomenon in recent years has been that large tech companies (e.g., IBM, SAP, etc.) have all launched their consulting services.

- The digital revolution that has unfolded in recent years has made IT and outsourcing consulting increasingly important. One important phenomenon of the recent years has been that large tech companies (e.g., IBM, SAP, etc.) have all launched their consulting services.

- Compared to other areas of consulting, HR consulting has developed relatively late, which can be explained by several reasons, one of the most common of which is the differences in region-specific trends and the differences in region-specific factors affecting HRM (human resource management) development. In the more developed economies of Western Europe, the first HR consulting companies were established as early as the 1940s. In addition to traditional HR consultants, more and more service providers are emerging to enter this market with new services (e.g., employee-renting, outsourcing, etc.).

- The new trends are well summarized by Brooks and Edwards (2014), who believe that in the field of management consulting instead of problem orientation, result orientation, instead of expert, co-creator, instead of static, dynamic knowledge creation, and instead of professional, personal relationships come to the fore.

However, it is also important to mention that, with the exception of a few cases and countries, counseling has not become a true academic discipline. This is explained by various authors (Srinivisan 2014), among others, that the consulting industry is very fragmented, there are innumerable companies in this field, the industry is not regulated and there is a lack of important in-depth academic research in this field. This particular situation may also seem strange because the works of great and acclaimed management gurus such as Argyris, Bennis, Ed Schein, McClelland, Nadler, or Porter have had a huge impact on this field, and even more of these have been under their own name or in association with others, they have established and operated recognized consulting firms.

All in all, this is not an insignificant industry. According to a recent survey conducted by IBIS market research, the global consulting industry had sales of $\$ 630$ billion in 2019. In addition to the well-known traditional strategic consulting firms (Bain, BCG, McKinsey, Mercer, etc.), this industry includes atypical consulting firms such as IBM, Tata or Infosys, known from the outsourcing industry, but we must not forget about the many micro, mini and mediumsized consulting firms that represent the waist army in this field in every country in the world.

The cradle of counseling, as previously indicated, was the United States. Mainly as a result of the Americanization of management, the consulting firms established there were able to gain a significant market position in Western Europe and South-East Asia "without any competitor" (Fröndhoff, 2020)

\section{CONSULTING MARKETS}

\section{Global consulting market}

There are relatively few data available on the size of global and regional consulting markets. According to the previously cited IBIS 2019 Global Management Consulting Industry Market Research Report, total revenue for the global management consulting industry reached \$ 634 billion in 2017 , with an average growth rate of 3.4\% over the past five years. The above-mentioned report finds that there are nearly 2 million consulting firms worldwide (38\% in the U.S.) that employ 4 million consultants. 


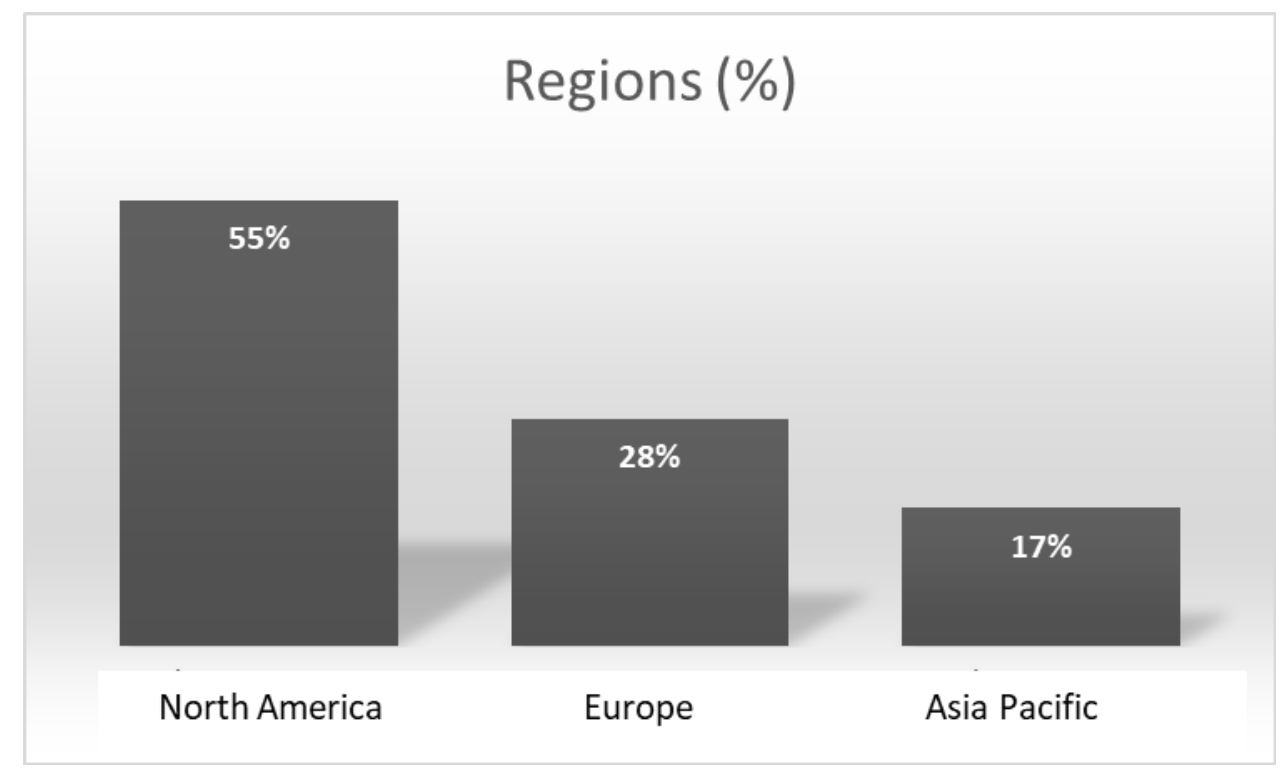

Picture 1: Distribution of the global consulting market by major regions Source: Authors own compilation by Consultancy.uk

\section{European consulting market}

According to the mentioned report, the second largest consulting market is the European, with its 28 percent share of the global market. The four largest markets are German, English, French and Spanish.

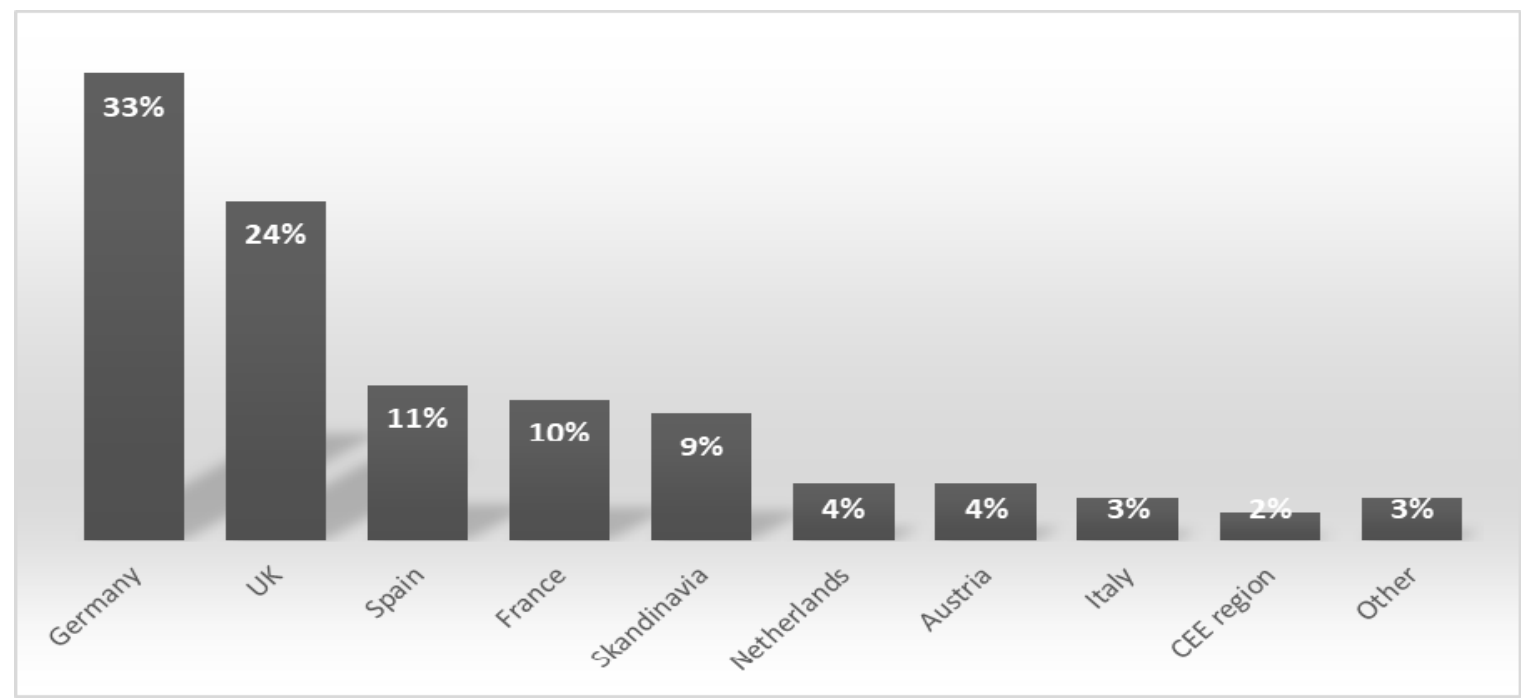

Picture 2: European advisory market share (2018)

Source: Authors own compilation by FEACO

\section{Eastern European consulting market}

Prior to the political changes in the late 1980s, advisory services in most Eastern European countries were provided by state-run sectoral research institutes, universities, or departments of individual ministries. In most countries, central institutions of management consulting have been set up with assistance of the International Labor Organization (ILO) or the United Nations' UNIDO. In these countries, the features of modern management consulting under the previous system were only found in traces. In most cases, the approaches to the previously mentioned trend of scientific leadership were typical.

After the regime change, privatization related consulting has developed significantly in all countries. Billions of euros have flowed into these countries through the European Union's PHARE program, and consultants have played a significant role in setting up and implementing the various programs. At the initiative of FEACO, advisory associations have been set up in almost all countries. The books and publications of Kubr (1996), who is of Czech descent but lived and worked in Geneva, have been translated into several local languages. Despite the indicated growth, Eastern Europe still represents a very modest part of the European consulting market. In recent years, the global decline in the field of 
counseling before the outbreak of the coronavirus epidemic has hardly been characteristic of our region. During the indicated period, consulting is one of the most developing economic services in Eastern European countries.

According to the latest data, the distribution of the consulting market, in the countries of Central and Eastern Europe is shown in the following picture.

\section{Distribution (\%)}

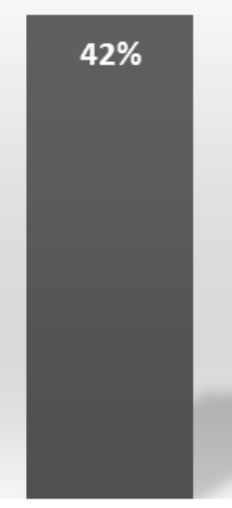

Poland

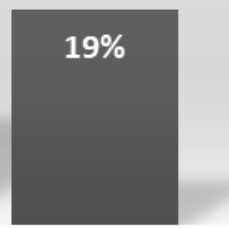

Romania

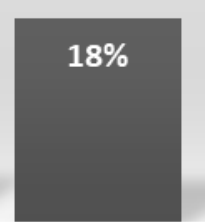

Czech Republic

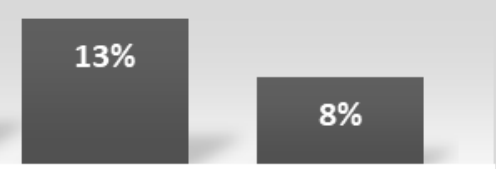

Hungary Slovakia

Picture 3: Distribution of the consulting market, in the CEE region by country (2018) Source: Authors own compilation by Source Global Research, 2018

\section{Hungarian consulting market}

By the turn of the millennium, the Hungarian consulting industry had reached the level of Greece and Portugal, which serve as a basis for comparison. Unfortunately, this good result did not lead to domestic companies and the public sector. In particular, the large-scale relocation of international companies has been an above-average driving force for the sector.

The majority of Hungarian consulting companies can actually be classified as small and medium-sized companies in terms of size. There are two typical groups of companies in the domestic consulting market. One of the groups can be classified as the so-called. big (Big Six later the Big Four) that offer all kinds of consulting services to their clients. The largest of the large international strategic consulting firms (e.g., McKinsey, BCG, Bain, Roland Berger), though, the socalled "General or complex or integrated MC services" consulting (also) has become increasingly involved, partly as a result of the proliferation of information technology (IT) and enterprise resource planning (ERP) systems.

The other group mainly provides specialized services (niche companies). Medium-sized players are missing from the Hungarian market. In connection with the analysis described above, it is important to point out that the described structure of domestic consulting looks very similar to the Hungarian corporate structure.

In the last decade, the typical users of consulting in Hungary have been mostly the private sector and, within that, multinational companies. Domestic SME clients did not play a significant role in this regard. In the last 4-5 years, advisory assignments from the public sector and the EU Structural Funds have provided the greatest opportunities.

A survey conducted in 2015 (Poór-Csapó, 2015) shows that domestic consulting firms use both expert, process, and more recently inquiry consulting approaches that are becoming increasingly fashionable. 


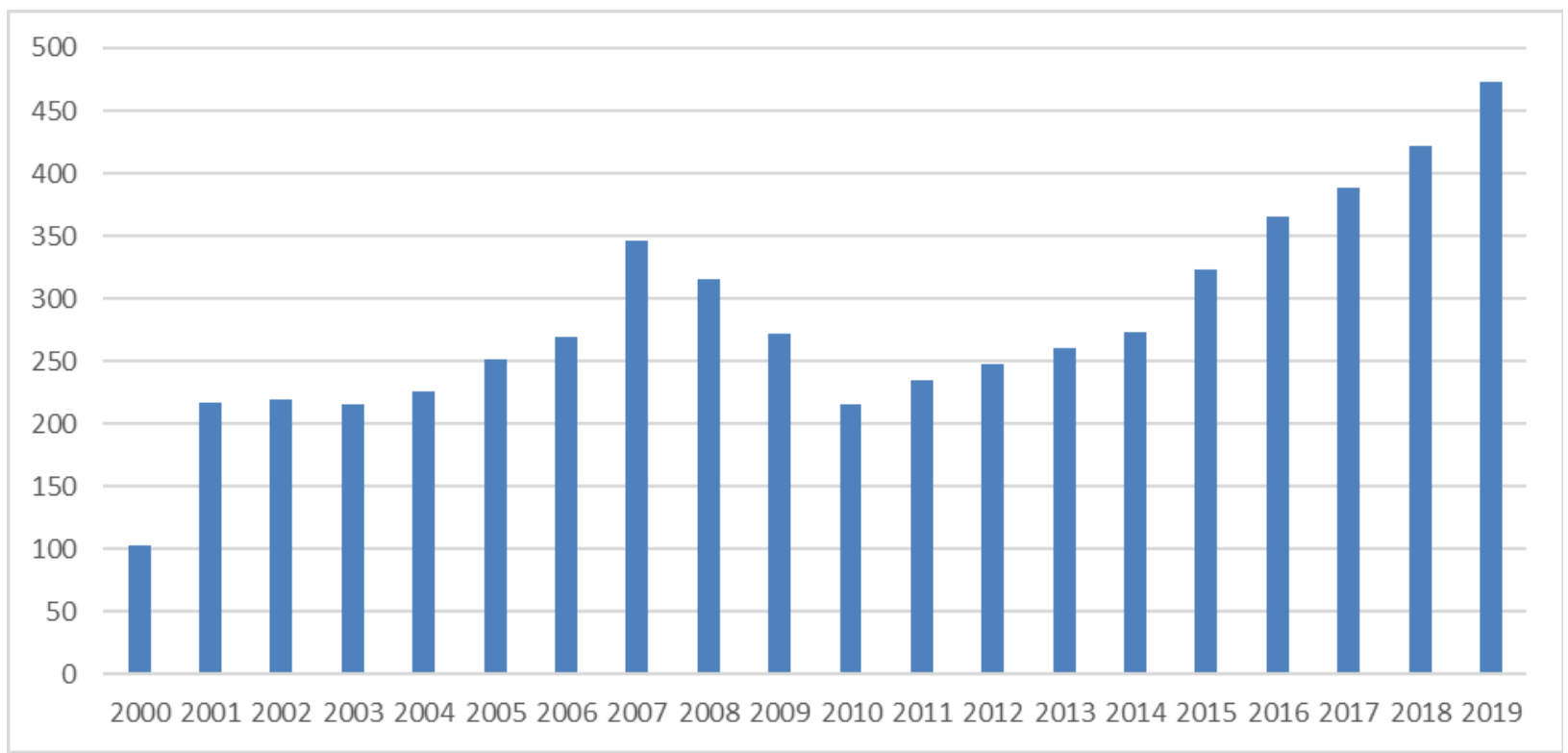

Picture 4: Management consulting in Hungary between 2000-2019

Source: Csapó l. (2021).

After the crisis of 2008-2009, a steady, more modest increase in volume can be observed in terms of the change in sales revenue, however, the sales revenue realized in 2007 was managed to be exceeded and exceeded by the Hungarian management consulting market only in 2016. Market volume growth has been growing steadily since 2016 until 2019 (Csapó, 2021)

\section{EFFECTS OF COVID 19 ON CONSULTING INDUSTRY}

The consulting industry has already been most significantly affected by the global pandemic in a number of ways. At the start of the outbreak in March 2020, the heads of the German divisions of four leading global strategic consulting firms (MCKinsey, Bain, BCG and Roland Berger) felt the following (Consultancy.eu., 2020). Advisers are regular travelers, so they are particularly sensitive to the spread of the virus, while the almost certainly provocable financial downturn of pandemic is likely to have a big impact on their income. In fact, as a result of the last financial crisis in 2008, the demand for consultants has fallen sharply, and many businesses have suffered greatly over the last decade to recover from it and be able to return to growth. This time, however, the heads of the German divisions of the four leading global strategic consulting firms said the medium-term outlook for the consulting market is much better than it was during the financial crisis. "

Many companies are wondering how this new situation and its economic consequences could be handled. Therefore, they continue to seek consultants and demand their services (Consultancy.eu., 2020). This is shared by labor professionals, who emphasize that "in the longer term, perhaps even more important is how receptive we are to learning, whether we will be able to recognize the wider context" (Csizmadia-Illés, 2020).

According to another study, also published in the Consultancy.eu website cited above, the decline in the consulting industry will be greatest in Europe (-28\%) and the US (-15\%) (consultancy.org, 2020). Handelsblatt, one of the most famous German economic journals, writes about a similar decline. According to the mentioned report, while the German consulting market, which has grown by almost 8-9 percent annually since 2010, realized sales of $€ 35$ billion in 2019 , a significant decline is expected. This decline is due to the cancellation or freezing of orders. Smaller consulting firms are more affected by this crisis. This is because many large consultancy projects, such as those for digital transformation, have not yet experienced a "shutdown" - but these will lengthen over time. These projects largely involve larger strategic consultants and IT professionals. In the case of personnel consultants, the situation is different, for example, when the downtime already leaves a clear mark on certain parts of the economy. Training and coaching projects are stopped by clients and they are also very reluctant to start looking for new managers. Important personal contacts and discussions in the field of human resources were currently barely possible at the time of closure. (Fröndhoff, 2020). The other research report (IBIS, 2021) published in January 2021 only a 6.5 percent global decline by 2020 . The research firm is already forecasting global growth in consulting industry by 2021 . That research report highlights that industries such as "certain technology industries and the pharmaceutical and healthcare sectors have performed better than companies with clients in hospitality and travel industries" (IBIS, 2021).

However, some analysts also suggest that during the pandemic, the relationship between awareness and paradigm shift will change. The epidemic will act as an accelerator in the processes that have actually been going on for years, namely, as companies increasingly rely on online solutions and blended learning concepts to improve the work of their staff. 
It should also be seen that reopening the economy is also an opportunity for change for the consulting industry. The latest business climate index from the German Advisory Association (BDU) indicates a clear improvement. Based on a survey of 800 consulting firms, the index shows a positive shift, in almost all areas (BDU, 2020).

In this situation, consulting firms, law firms, and other professional service providers prefer to send their employees home to work from home. This situation, in turn, raises a number of data security issues. That the employees of these companies can provide the usual and expected confidential data and information management, as in the office environment. While professional services firms operating remotely in the form of a home office present new and different risks, these risks can be significantly reduced through careful ongoing management, communication and training (Rowlands, 2020).

The specific communication effects of Covid are raised by the leaders of various professional service companies. In the new situation, such companies have successfully maintained their formal communications and are likely to increase their effectiveness, but occasional, problem-solving innovative conversations are not easy to hold in such an environment (Keogh, 2020).

It is often worthwhile for consultants to build on older examples to find an effective and innovative solution for today's COVID-affected companies. The McKinsey Global Research Institute's regular business newsletter provides a number of examples of this. "We looked at the post-World War II era, when countries rebuilt from the ashes to come up with ideas that are just as relevant now. Finally, we have identified ways in which managers can change their mindsets and behaviors to reopen their business safely" (MC Kinsey, 2020). During the current crisis, indications have emerged that we have seen very often during the 2008-2009 crisis, i.e., "Enough of the consultants, rather internal staff is used to solve our problems" (Morris-Noonan, 2020).

\section{EMPIRICAL RESEARCH}

\section{Research methods}

Our research team conducted an empirical survey between November 10 and December 10, 2020. During the research, we examined the impact of the COVID-19 epidemic on the Hungarian consulting industry. The survey, implemented in the form of a questionnaire survey, was carried out with the support of the professional associations operating in Hungary (HSZOSZ, MÉT, OHE, PMSZ, SZMT, TANOSZT, TK, VOE and VTMSZ).

Participation in the survey was voluntary and free of charge, and the data will be kept confidential. The questionnaire was completed online. It was a single-responder query, meaning an organization means fill.

In our research, we sought answers to the following with our questionnaire containing 14 questions:

- Characteristics of the enterprises responding to our questionnaire (size, sector, turnover, year of establishment and form of enterprise).

- $\quad$ Potential and perceived economic impacts of COVID-19 (revenue, headcount and service activity).

- Potential and perceived effects of COVID-19 on consultancy work (for already contracted projects, for new projects, in consultancy work).

- $\quad$ Finally, we also asked what opportunities the respondents see in the advisory work following COVID-19.

\section{About our sample}

According to the definition of almost half of the respondents, micro-consulting enterprises can be classified into the category, most of these organizations operate with 2-9 employees. Small and medium-sized (SME) enterprises make up one third of the respondents in the sample. The share of organizations employing more than 250 people is close to 20 percent. The distribution of the responding organizations by headcount is shown in Table 1.

Table 1: Responding organization size - number of employees (for complex large companies, only the size of the consulting business chapter was taken into account here)

Table 1: Responding organization size - number of employees (for complex large companies, only the size of the consulting business chapter was taken into account here)

\begin{tabular}{|l|l|l|l|}
\hline No. & $\begin{array}{l}\text { Headcount } \\
\text { (persons) }\end{array}$ & Frequencies & $\%$ \\
\hline 1. & 1 & 49 & $21,4 \%$ \\
\hline 2. & $2-9$ & 67 & $29,3 \%$ \\
\hline 3. & $10-49$ & 34 & $14,8 \%$ \\
\hline 4. & $50-250$ & 37 & $16,2 \%$ \\
\hline 5. & $251-500$ & 8 & $3,5 \%$ \\
\hline 6. & $501-1000$ & 12 & $5,2 \%$ \\
\hline
\end{tabular}




\begin{tabular}{|l|l|l|l|}
7. & above 1000 & 22 & $9,6 \%$ \\
\hline & Total & 229 & \\
\hline
\end{tabular}

Source: Authors' own research

The largest proportion of respondents came from domestically owned private enterprises, with a share of 64 and a half percent in the sample. The share of foreign or jointly owned private companies is nearly one-third of the sample. Public sector organizations are included in the survey in the smallest proportion. The distribution of respondents by form of ownership is shown in Table 2.

Table 2: Ownership of responding organizations

\begin{tabular}{|l|l|l|l|}
\hline No. & Ownership & Frequency & $\%$ \\
\hline 1. & Domestic privately owned & 145 & $64,4 \%$ \\
\hline 2. & Domestic publicly owned & 14 & $6,2 \%$ \\
\hline 3. & Foreign privately owned & 47 & $20,9 \%$ \\
\hline 4. & Mix & 19 & $8,4 \%$ \\
\hline & Total & 225 & \\
\hline
\end{tabular}

Source: Authors' own research

Our respondents include organizations of different ages in approximately the same proportion, about 11 percent of which were formed before the change of regime and almost 10 percent after 2015. The distribution of responding organizations by period of establishment is shown in Table 3.

Table 3: Year of establishment of responding organizations

\begin{tabular}{|l|l|l|l|}
\hline No. & Year of establishment & Frequency & $\%$ \\
\hline 1. & after 2015 & 20 & $9,5 \%$ \\
\hline 2. & $2011-2015$ & 23 & $11,0 \%$ \\
\hline 3. & $2006-2010$ & 43 & $20,5 \%$ \\
\hline 4. & $2001-2005$ & 34 & $16,2 \%$ \\
\hline 5. & $1996-2000$ & 34 & $16,2 \%$ \\
\hline 6. & $1990-1995$ & 33 & $15,7 \%$ \\
\hline 7. & bevor 1990 & 23 & $11,0 \%$ \\
\hline & Total & 210 & \\
\hline
\end{tabular}

\section{Impacts on Consulting business}

Source: Authors' own research

In this context, we examined the development of the following three business characteristics:

- Revenue: The coronavirus crisis in 2020 affected consulting organizations in very different ways. About threequarters of the 261 respondents answered the question of how sales in your organization will develop in 2020 compared to the previous year. Nearly a quarter of them said they would not experience significant changes. In their opinion, the sales revenue will be similar to the sales revenue in 2019. Slightly more than that, almost a third of respondents report a decline in sales of more than 10 percent. The data show that the coronavirus crisis is causing a decrease in sales revenue in almost half of the companies $(43.6 \%)$. We can also see a positive result, with about 20 per cent of respondents experiencing an increase of around 10 per cent or more.

- Headcount: Three-quarters of the respondents also provided information on the development of the organization's headcount during the survey. For most of them (67\%), the number of employees did not change compared to the previous year. About 20 percent of respondents report a decline in the workforce, while 10 percent report the proportion of organizations in the sample where the workforce has increased despite the coronavirus crisis.

- Consulting services: Based on the responses of the organizations participating in the survey, it can be observed that the current coronavirus crisis has had an impact on the frequency of recourse to counseling services. A relatively large proportion of respondents, 42 per cent, reported a decrease in the number and volume of counseling services they provided in 2020 compared to the previous year. A further 6 per cent marked the "had to pause" option. Nearly one-third of the organizations did not experience a change in the number of services provided. An increase of 20 percent of respondents experienced an increase.

- Opportunities in a crisis: The vast majority of respondents agree that the crisis also has opportunities that are just waiting to be discovered and exploited. 


\section{CONCLUSION}

In the last year of the last decade, very high growth rates approaching 10 percent were not uncommon in the advisory sector of the economies of the developed world and transition countries either. Studying the data of recent years, it can be clearly stated that the development of the consulting sector in a given economy is clearly influenced in a positive direction by economic development (GPD), cultural openness and confidence.

The outbreak of COVID-19 (Coronavirus Disease) at the end of the decade, which affected almost all actors in socioeconomic life, was completely unexpected. Consulting firms were not excluded from the indicated effects either. Most of these companies were very negatively affected by the epidemic. But similar to certain business sectors (e.g., IT, logistics, warehousing, etc.), many consulting firms in this area have seen significant growth.

Of course, we could not go into all the important details of the development of this field within the narrow framework. In turn, we highlighted some of the most important global, regional and local trends and tendencies. We do not consider our research as final. We will soon be launching consultancy research in this area, covering at least ten countries on our continent as well as the United States

\section{REFERENCES}

BDU Bundesverband Deutscher Unternehmensberater (2020). Pressemitteilung. Geschaeftklima Consulting. BDU, Bonn

Consultancy.org (2020). The impact of the Coronavirus on the global consulting industry. Retrieved August 10, 2020 from https://www.consultancy.org/news/162/the-impact-of-the-coronavirus-on-the-global-consulting-industry

Csapó I. (2021). Changes in management consulting methods in a dynamically changing environment. Unpublished doctoral dissertation, Hungarian University of Agricultural and Life Sciences, Gödöllö.

Csizmadia, P., \&lllésy, M. (2020, April 30). A nagy leállás: a magyar munkahelyek közel fele került veszélybe. Social Science Research Center Institute of Sociology Retrieved August 5, 2020 from https://szociologia.tk.mta.hu/uploads/files/Csizmadia-Illessy_A_virus_es_a_munka-F.pdf

Fröndhoff, B. (2020. April, 20). Coronakrise lässt den Beratermarkt schrumpfen. Handelsblatt Retrieved August 10, 2020 from https://www.handelsblatt.com/unternehmen/dienstleister/consulting-coronakrise-laesst-den-beratermarktschrumpfen/25756640.html?ticket=ST-2844213-Mff6GYf5YeEiqbhUoTMW-ap4

IBIS (2019). World Report 2019. Industry trends, global industry reports. Retrieved July 26, 2019 from https://www.ibisworld.com/industry-trends/global-industry-reports/business-activities/management-consultants.html

IBIS (2021). Global Management Consultants Industry - Market Research Report. Retrieved April 1, 2021 from Global Management Consultants - Industry Data, Trends, Stats | IBISWorld

Keogh, O. (2020 June 26). Professional services firms face plethora of post-Covid challenges. The Irish Times Retrieved August 10, 2020 from https://www.irishtimes.com/business/work/professional-services-firms-face-plethoraof-post-covid-challenges-1.4286313

Kubr, M. (1996). Management Consulting A Guide to the Profession. International Labour Office, Geneva.

Morris, S., \&Noonan, L. (August 5, 2020). Wells Fargo to dramatically cut consultancy spend after internal backlash. Financial Times. Retrieved August 10, 2020 from https://www.ft.com/content/abe2ebc2-8f7d-45c7-964e678b48f9baed

Pereira, L. F., Jerónimo, C. M., \&Ramos, M. R. (2017). Management consulting business models. A perspective of sustainability. 2017 International Conference on Engineering, Technology and Innovation (ICE/ITMC). (Pages 29-35). Retrieved May 10, 2018 from https://repositorio.iscteiul.pt/bitstream/10071/16468/1/Management\%20Consulting.pdf

Peters, Th. J. \&Waterman R. H. (1982). In Search of Excellence: Lessons from America's Best-run Companies. Harper \& Row, New York. https://doi.org/10.1177\%2F019263658306746628

Plunkett, J. W. (2018). Major trends affecting the consulting industry. In: Plunkett's Consulting Industry Almanac. Plunkett Research, Houston.

Poór J. \&Csapó I. (2015). Changes in management consulting methods Hungary - 2015 (research report) Chamber of Commerce and Industry -Tanoszt -TOP- SZIE MHR. Budapest.

Poór, J. (2016). Management consulting handbook. Akademiai Publishing House, Budapest.

Rowlands, H. (April 20, 2020). COVID-19 Professional Services: Risk issues around working remotely: data and documents. Retrieved August 5, 2020 from https://www.clydeco.com/en/insights/2020/04/covid-19-uk-risk-issuesaround-working-remotely-da 
Srinivisan, R. (2014). The management consulting industry: Growth of consulting services in India. Panel Discussion. IMB Management Review, 26 (4), 257-270. https://doi.org/10.1016/j.imb.2014.09.001 